\title{
You Didn't Build That: The Case Against Patentability of Isolated Organisms
}

\author{
Cliff Brazil
}

\section{INTRODUCTION}

If you walked into the woods and discovered a new type of mineral, picked it up, and brought it back to society, would you be entitled to a patent for that mineral? What if that mineral weighed two tons or was buried deep underground, and it required substantial financial resources and hard work to retrieve it? The answer to both of these questions is unequivocally no. ${ }^{1}$ Now what if you went out into the woods, discovered a new type of bacterium in the soil, retrieved it from the soil, and brought it back to society, would you be entitled to a patent then? The answer is, surprisingly, yes. ${ }^{2}$ What characteristic does an isolated naturally occurring organism have that a naturally occurring mineral lacks that makes the isolated organism eligible for a patent?

This Comment will argue there is no distinction between these two discoveries: neither should merit a patent. Rather, due to the conflation of two distinct patent law requirements, patent eligible subject matter under 35 U.S.C. $\S 101^{3}$ and novelty under 35 U.S.C. $\S 102(a),{ }^{4}$ the

\footnotetext{
* J.D. 2014, University of Kansas School of Law; B.S. 2011 Colorado School of Mines. I would like to thank Professor Andrew Torrance for his help, his willingness to engage in longwinded debates with me regarding this topic, and his critiques. I would also like to thank the University of Kansas Law Review Board and Staff for their hard work and help in publishing this paper.

1. See Ass'n for Molecular Pathology v. Myriad Genetics, Inc., 133 S. Ct. 2107, 2117 (2013) (stating "groundbreaking, innovative, or even brilliant discovery does not by itself satisfy the $\S 101$ inquiry."); Diamond v. Chakrabarty, 447 U.S. 303, 309 (1980) (stating "a new mineral discovered in the earth or a new plant found in the wild is not patentable subject matter.").

2. John Edward Schneider, Microorganisms and the Patent Office: To Deposit or Not to Deposit, That is the Question, 52 FoRDHAM L. REV. 592, 593 n.12 (1984) (identifying three separate patents on microorganisms isolated from nature).

3. 35 U.S.C. $§ 101$ (2012). Section 101 states: "Whoever invents or discovers any new and useful process, machine, manufacture, or composition of matter, or any new and useful improvement thereof, may obtain a patent therefor, subject to the conditions and requirements of this title."

4. 35 U.S.C. $\S 102$ (a) (2012). Section 102(a) states: "A person shall be entitled to a patent unless - (1) the claimed invention was patented, described in a printed publication, or in public use, on sale, or otherwise available to the public before the effective filing date of the claimed invention; or (2) the claimed invention was described in a patent issued under section 151, or in an application
} 
requirement that an invention be "made by man" has been rendered unclear, and is made all the more difficult by the advanced and complex nature of biotechnology. By applying a doctrine intended to go only to the novelty of an invention over the prior art, patents are being granted on "inventions" not made by man: isolated microorganisms. These microorganisms are merely plucked from their surroundings; they are not in any way altered by human hands. However, according to the current Patent Office practice, this mere act of isolation entitles the person who first isolates the microorganism to a patent claiming the microorganism itself.

This Comment will argue that the practice of granting patents on isolated organisms is improperly extending the scope of proscribed eligible subject matter under 35 U.S.C. $\S 101$ because isolated organisms fall within the "product of nature" exception to patent eligible subject matter. Part II will provide the precedent for the isolation and purification doctrines of law, as they pertain to both the requirement of novelty and patent eligible subject matter. The law as it pertains to novelty is often conflated with the law in regards to patent eligible subject matter, understanding the basis of both is paramount. Part II will also argue that the isolation/purification doctrine regarding novelty is a legal fiction, and can be better addressed by the other already existing patent law requirements. With this precedent in mind, Part II will then synthesize an isolation/purification framework that can be used to determine if an isolated or purified substance is patent eligible subject matter. Part II will conclude by discussing the Patent Office's policy on isolated organisms and the foundation for the policy. Part III will begin by explaining why the Patent Office's foundation for granting isolated organism patents, In re Bergy, ${ }^{5}$ is weak, as it conflates the law as it pertains to novelty with that of patentable subject matter. Then, Part III will evaluate a patent and a patent application claiming isolated microorganisms to demonstrate the isolation/purification framework and to show why the subject matter of these patents should be outside the scope of $\S 101$. Part IV will then provide concluding remarks regarding the framework.

for patent published or deemed published under section 122(b), in which the patent or application, as the case may be, names another inventor and was effectively filed before the effective filing date of the claimed invention."

5. 563 F.2d 1031, (C.C.P.A. 1977), vacated, Parker v. Bergy, 438 U.S. 902 (1978). 


\section{BACKGROUND}

\section{A. Patent Law}

Patent law exists as a mechanism to benefit society by protecting the works of inventors, thus incentivizing inventors to invest their time, effort, and money developing technologies that benefit all of society. ${ }^{6}$ The founders sought to draft the patent laws using broad language, following the philosophy of Thomas Jefferson that "ingenuity should receive a liberal encouragement."7 Thus, the United States Constitution was drafted to grant Congress the power "[t]o promote the Progress of Science and useful Arts, by securing for limited Times to Authors and Inventors the exclusive Right to their respective Writings and Discoveries." 8 Indeed, by the time the Patent Act of 1952 was enacted, it was intended that inventors should be able to get a patent on "anything under the sun that is made by man.",

However, in exercising this power, Congress did choose to limit the type of subject matter eligible for patentability. 35 U.S.C. $\S 101$, titled Inventions Patentable, states "whoever invents or discovers any new and useful process, machine, manufacture, or composition of matter, or any new and useful improvement thereof, may obtain a patent therefor, subject to the conditions and requirements of this title."10 This provision provides for four categories of patentable subject matter: processes, machines, manufactures, and compositions of matter. ${ }^{11}$ The expansive nature of these categories is in line with Congress' intent for the patent laws to "include anything under the sun that is made by man." 12

Despite this broad reading of patentable subject matter, not everything falls within the scope of $\S 101$ : laws of nature, physical phenomena, and abstract ideas are three such exclusions from patentable subject matter. ${ }^{13}$ While the Court views these as subject matter exclusions, laws of nature and physical phenomena can really be viewed

\footnotetext{
6. Alan L. Durham, Patent Law Essentials: A Concise Guide 2 (4th ed. 2013).

7. Diamond v. Chakrabarty, 447 U.S. 303, 308-09 (1980) (quoting 5 Writings of Thomas Jefferson 75-76 (Washington ed. 1871)).

8. U.S. CONST. art. I, $\S 8$, cl. 8 .

9. Chakrabarty, 447 U.S. at 309 (quoting S. REP. No. 82-1979, at 5 (1952); H.R. REP. No. 82 1923 , at $6(1952))$.

10. 35 U.S.C. $\S 101(2012)$.

11. Id.

12. S. REP. No. 82-1979, at 2399 (1952); H.R. REP. No. 82-1923, at 2399 (1952).

13. See Chakrabarty, 447 U.S. at 309.
} 
as absolute bars to novelty: a patent on a law of nature or physical phenomena can never be new, as it first existed in nature.

35 U.S.C. $\S 102$ requires that an invention be "novel" in order to be entitled to a patent. ${ }^{14}$ Because the laws of nature and physical phenomena subject matter exclusions are really absolute novelty bars, certain aspects of the "novelty" jurisprudence have been conflated with the eligible subject matter jurisprudence of $\S 101 .{ }^{15}$ One such aspect is the law of novelty as it pertains to isolated and purified forms of the prior art. ${ }^{16}$ Thus, to understand why the current practice of granting patents on isolated organisms is outside the scope of $\S 101$, a proper understanding of the underpinnings of the "isolation/purification" doctrine as it pertains to novelty and patent eligible subject matter is necessary.

\section{The Wood-Paper Patent Case}

Perhaps the earliest case to mention the isolation/purification question was The Wood-Paper Patent case. ${ }^{17}$ The Wood-Paper Patent case focused on, among other things, a reissue patent to Watt \& Burgess, numbered 1448, and owned by the American Paper Company. ${ }^{18}$ The 1448 patent was directed to a product: "a pulp suitable for the manufacture of paper, made from wood or other vegetable substances."

The alleged infringer in the case, the Fibre Disintegrating Company, argued that the 1448 patent was invalid as lacking novelty. ${ }^{20}$ The use of pulp in making paper had been known prior to 1853, the year the 1448 patent was filed, and in fact many patents had been issued relating to the pulp and the process of making it. ${ }^{21}$ However, prior to Watt \& Burgess, no pulp-making process produced pulp in a condition of purity in a first instance, but instead could be later purified after the initial step. ${ }^{22}$ While these old methods did not produce pure pulp, the pulp nonetheless was suitable for the making of paper.

American Paper Company argued, however, that because the pulp from their process was pure, and all prior attempts to produce pulp lead

\footnotetext{
14. 35 U.S.C. $§ 102(a)(2012)$.

15. See discussion infra Part II.B.

16. See discussion infra Part II.B.

17. Am. Wood-Paper Co. v. Fibre Disintegrating Co. (The Wood-Paper Patent), 90 U.S. 566 (1874).

18. Id. at 593

19. Id. at 594 .

20. Id.

21. $I d$.

22. Id. at 597
} 
to pulp that was not pure, their pulp was a "new" product, thus meriting patent protection. ${ }^{23}$

The Court disagreed. The Court noted that "it is quite obvious that a manufacture, or a product of a process, may be no novelty, while, at the same time, the process or agency by which it is produced may be both new and useful." ${ }^{24}$ Similarly, the Court noted that merely extracting a known product in a new way does not make the known product itself new. ${ }^{25}$ The Court then doubted whether "a slight difference in the degree of purity of an article... justifies denominating the products different manufactures," but declined to decide that issue, as the product claimed was to "pulp suitable for the manufacture of paper," rather than to a purified pulp product. ${ }^{26}$

While the Court did not answer the question of whether a purification of a known product could be deemed "novel," and while The Wood-Paper Patent case did not pertain directly to $\S 101$ issues of patentable subject matter, the discussion is nonetheless insightful when $\S$ 101 is viewed as an absolute bar to novelty.

\section{Kuehmsted v. Farbenfabriken of Elberfeld Co.}

One year prior to the Parke-Davis \& Co. v. H.K. Mulford Co. ${ }^{27}$ decision, the Seventh Circuit heard a case involving aspirin. ${ }^{28}$ At the time of the case, no known medicine existed that had the therapeutic properties of the claimed aspirin. ${ }^{29}$ However, an inventor by the name of Kraut had previously claimed to invent what he thought was acetyl salicylic acid (aspirin). ${ }^{30}$ Hoffman, the inventor of the claimed aspirin at issue, stated however that because he had used a different procedure and obtained a chemical with entirely different properties from that of Kraut, he had in fact actually obtained acetyl salicylic acid, and Kraut was mistaken. ${ }^{31}$ Appellant, however, asserted the two compounds were the same because they had the same chemical formula and responded to the same tests. ${ }^{32}$ Thus, appellant contended that the claimed aspirin was

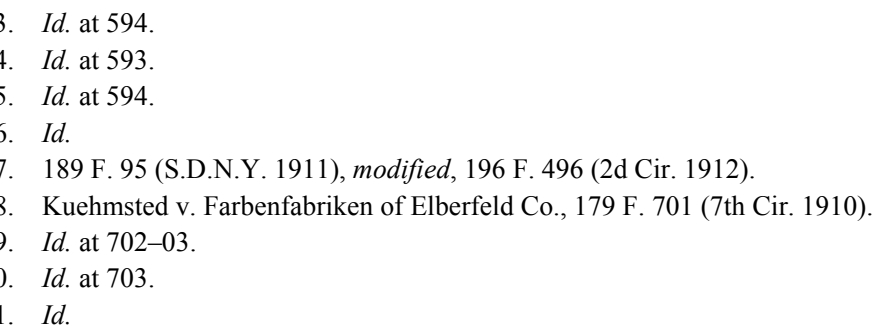


merely the purified form of the Kraut compound, and therefore not entitled to patent protection. ${ }^{33}$

The court started by noting that the mere fact that the chemical formula was the same for both compounds was of little impact to the analysis. $^{34}$ This is because two compounds having the same formula could differ widely depending on the level and kind of impurities present. ${ }^{35}$ Having disposed of this contention, the court turned to the response of both compounds to the same tests. ${ }^{36}$ First, the Kraut compound did not react the same way as Hoffman's when it was boiled in water. ${ }^{37}$ Appellant then maintained that he could, through a process involving boiling water, arrive at the Hoffman compound. ${ }^{38}$ This was not enough to suggest that the two compounds were the same, but in fact was just evidence that the Kraut compound could be treated and processed in such a way as to produce some portions of the Hoffman compound. $^{39}$

Moreover, even if the two compounds were chemically and analytically the same, Hoffman's recrystallized product provided completely different therapeutic qualities from Kraut's: Hoffman's compound was the first to overcome the downsides of salicylic acid without sacrificing its benefits. ${ }^{40}$ This compound was an unquestionable benefit to mankind, "something new in a useful art, such as our patent policy was intended to promote." 41 It was irrelevant to the court that "the medicine thus produced is lifted out of a mass that contained, chemically, the compound; for, though the difference between [the compounds] be one of purification only ... patentability would follow. In the one case the mass is made to yield something to the useful arts; in the other case what is yielded is chiefly interesting as a fact in chemical learning." While this holding wanders into the separate area of "utility," its language on purification is of greater significance.

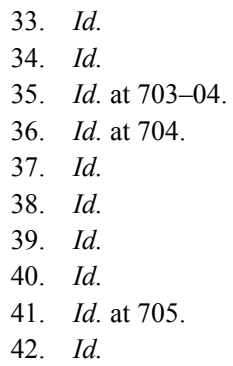




\section{Union Carbide v. American Carbide Co.}

A second case also decided one year prior to Parke-Davis ${ }^{43}$ was Union Carbide v. American Carbide Co ${ }^{44}$ The Second Circuit decided Union Carbide, making it directly binding on Judge Learned Hand. ${ }^{45}$ The claimed invention at issue was crystalline calcium carbonate, a new form of calcium carbonate that had not previously existed. ${ }^{46}$ The alleged infringer contended that this was not patently novel over amorphous calcium carbonate, as it was merely a new form of the same composition. ${ }^{47}$

But the court disagreed, noting that "patentable novelty ... may be founded upon superior efficiency; upon superior durability, including the ability to retain a permanent form when exposed to the atmosphere; upon a lesser tendency to breakage and loss [and] upon purity."48 This crystalline form of calcium carbide provided a far greater yield than the amorphous calcium carbide, thus providing a patentable difference over the prior art. ${ }^{49}$ Thus, it was within the patent laws to uphold the claimed calcium carbonate. ${ }^{50}$ But the court went one step further, noting that it was not just lawful, but also just, because "[t]o hold an important discovery which has given to the world a commercially new product ... not entitled to protection for want of novelty, would, as it seems to us, be applying the patent statute to defeat its fundamental purposes." 51

\section{Parke-Davis \& Co. v. H.K. Mulford Co.}

Over a century ago, Judge Learned Hand laid the doctrinal foundation for the patenting of isolated organisms in Parke-Davis \& Co. v. H.K. Mulford Co. ${ }^{52}$ The patent at issue in Parke-Davis concerned a pure and stable form of a naturally occurring chemical found in the suprarenal glands of certain animals. ${ }^{53}$ This purified version of the

\footnotetext{
43. Parke-Davis \& Co. v. H.K. Mulford Co., 189 F. 95 (S.D.N.Y. 1911), modified, 196 F. 496 (2d Cir. 1912).

44. 181 F. 104 (2d Cir. 1910)

45. Id.

46. Id. at 104 .

47. Id. at 106 .

48. Id. at $106-07$.

49. Id. at 107 .

50. Id. at 108 .

51. $I d$

52. 189 F. 95 (S.D.N.Y. 1911), modified, 196 F. 496 (2d Cir. 1912).

53. Parke-Davis, 196 F. at 497 (discussing the patent at issue in the lower court and decided by Learned Hand).
} 
chemical maintained the same physiological characteristics of the natural chemical-"hemostatic, blood pressure raising, and astringent properties"- but managed to achieve these properties in a satisfactory way that the natural chemical could not. ${ }^{54}$ Judge Hand noted that the patentee was the first person to successfully isolate this substance in a pure form; however, he did not view the claimed chemical composition as merely a more pure version of the natural chemical, but as a distinct compound altogether. ${ }^{55}$ The claimed compound did not include a salt and the natural compound only existed in nature in a salt form. ${ }^{56}$ Thus, the claimed compound was a separate and distinct compound. ${ }^{57}$

Far more controversial, however, was Judge Hand's next assertion: it would have been irrelevant if the claimed composition were merely unchanged after being extracted from the animal. ${ }^{58}$ According to Judge Hand, "there is no rule that [extracted products without change] are not patentable." 59 However, Judge Hand was mistaken on this point. As discussed above, the Supreme Court in The Wood-Paper Patent case expressly stated that a product that is known and merely extracted "cannot be called a new manufacture." $"$ Judge Hand relied on the above-discussed Union Carbide as authority. ${ }^{61}$ However, Union Carbide did not suggest that extracted products are patent eligible, but rather upheld a patent that claimed an entirely new form of a chemical compound that did not exist in nature and was novel as to prior art carbide patents. ${ }^{62}$ By viewing the products of nature exception as an absolute bar to novelty, it becomes clear why the patent in Union Carbide warranted patent protection, while the patent in Parke-Davis should have been struck down. The crystallized form of calcium carbonate had not existed in nature, and thus was not "anticipated" by nature. Thus the absolute bar to novelty does not apply. By contrast, there is the hypothetical patent on the extracted product suggested by Judge Hand in Parke-Davis. This extracted product did exist in nature prior to the patent, and therefore is anticipated by nature.

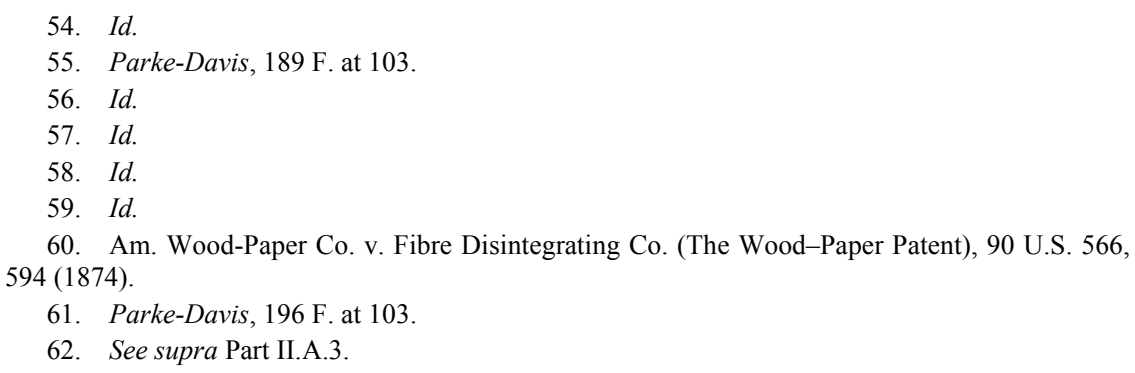




\section{General Electric Co. v. De Forest Radio Co.}

The next court to address the issue of isolation and purification was the Third Circuit in 1928 in General Electric Co. v. De Forest Radio Co. ${ }^{63}$ The patent at issue in General Electric was to "tungsten and method of making the same for use as filaments of incandescent electric lamps and for other purposes." ${ }^{44}$ Initially, the patent was granted because it was believed that tungsten found in nature was highly brittle and incapable of being turned into wires. ${ }^{65}$ Thus, when the patentee managed to take the natural tungsten and through his process create a metal with new properties not found in natural tungsten, it was believed he had invented a new metal that was not pure tungsten, and therefore entitled to a patent. ${ }^{66}$ However, it was later determined that the "natural" tungsten was in actuality an oxide of tungsten, $\mathrm{WO}_{3}$, and the patentee had merely managed to separate the tungsten from the oxide form. ${ }^{67}$ The issue then was "whether the tungsten of which the patent speaks is the tungsten of nature with its inherent quality of ductility or is a new metal produced by [the patentee] which is wholly different from anything that nature provides." 68

The court started by noting the principle that "[i]f [the metal] is a natural thing then clearly... he cannot have a patent for it because a patent cannot be awarded for a discovery or for a product of nature, or for a chemical element." ${ }^{69}$ The court began by discussing how the patentee had obtained the pure tungsten. The patentee "took tungsten as it 'existed' (WO3) or as it is found in the earth, its native abode, and by his process converted it into pure tungsten." ${ }^{.70}$ Thus, the patentee had merely discovered the natural properties of tungsten inherent to it, not created by any man. ${ }^{71}$ For that reason, the patentee was not entitled to the patent. ${ }^{72}$

\footnotetext{
63. 28 F.2d 641 (3d Cir. 1928).

64. Id. at 641 .

65. Id. at 642 .

66. $I d$.

67. Id.

68. $I d$.

69. Id. (citing United States Indus. Chem. Co., Inc. v. Theroz Co., 25 F.2d 387, 391-92 (4th Cir. 1928)).

70. Id.

71. Id. at 643 .

72. Id.
} 


\section{Funk Bros. Seed Co. v. Kalo Inoculant Co.}

The rule from General Electric was expanded in Funk Bros. Seed Co. v. Kalo Inoculant Co. ${ }^{73}$ where the Court was asked to determine whether a patent for a mixture of naturally occurring strains of bacteria was patent eligible. ${ }^{74}$ The bacterium at issue were naturally occurring root nodule bacteria that aid leguminous plants in the fixing of nitrogen from the air which is later converted in the plant for organic nitrogenous compounds. ${ }^{75}$ Prior to the patent at issue, it was well known that there were six such species of these root nodules, and that each species is distinct from one another with varying nitrogen-fixing efficiency. ${ }^{76}$ It was further known how to select the strains that were strongest to produce a culture that are then placed in a powder or liquid and sold to be used in the inoculation of seeds. ${ }^{77}$ However, up until the patent at issue, most inoculants were single species inoculants, and those mixtures that existed proved to be unsatisfactory. ${ }^{78}$ It was believed that the different species present in the early mixtures were mutually inhibitive upon one another, thus nullifying the benefit of creating the mixture. ${ }^{79}$

The patent at issue was thus a mixture that managed to solve the problems present in the previous mixtures. ${ }^{80}$ The inventor of the mixture, Bond, had managed to discover new strains that did not cause the mutually inhibitive properties present in the earlier generation mixtures. ${ }^{81}$ His patent then, provided for a novel mixture of root nodule bacteria strains that were capable of inoculating multiple types of seeds, a feat prior mixtures could not accomplish. ${ }^{82}$ It was this mixture the Court was asked to consider.

Despite the novel nature of the mixture at hand, the Court invalidated the claims to the mixture. ${ }^{83}$ The non-inhibitive quality of the mixture at issue was not created by Bond, but rather was a quality provided to the bacteria by nature. ${ }^{84}$ As such, the mixture could not be patentable as it

73. 333 U.S. 127, 131-32 (1948)

74. Id. at $128 \mathrm{n} .1$.

75. Id. at 128 .

76. Id. at 129 .

77. $I d$.

78. Id.

79. Id.

80. Id.

81. Id. at 130 .

82. Id.

83. Id. at 131 .

84. Id. at 130 . 
falls within the "laws of nature" exception to $\S 101 .^{85}$ In the Court's view, the mere "aggregation of species" did not move the mixture into the scope of eligible subject matter. ${ }^{86}$ It is immaterial that the discovery made was ingenious and that the mixture did in fact have advantages to the mixtures that came before it, "but a product must be more than new and useful to be patented; it must also satisfy the requirements of invention or discovery." 88

\section{Diamond v. Chakrabarty}

Parke-Davis and Funk, while laying important foundation for patents on isolated organisms, could not alone usher in a wave of new patents on isolated organisms. One key question still needed to be answered: is life patentable? The answer came in 1980, when the Supreme Court decided Diamond v. Chakrabarty. ${ }^{89}$ As a scientist at General Electric, Dr. Chakrabarty had developed a bacterium, pseudomonas bacterium, which could break down crude oil and other environmental pollutants. ${ }^{90}$ It was this bacterium that was the subject of the patent at issue in Chakrabarty.

Dr. Chakrabarty filed his patent application in 1972 and, in it, asserted 36 claims related to the bacterium. ${ }^{91}$ This bacterium was the product of human invention and the oil degrading property of the bacterium was not found in any natural bacterium. ${ }^{92}$ The patent application included three types of claims: process claims related to creating the bacteria, claims to an inoculum (comprising the bacteria and a carrier material), and the bacteria itself. ${ }^{93}$ The patent examiner allowed the first two categories of claims during the application process, but rejected the claims to the bacteria itself. ${ }^{94}$ The examiner gave two reasons for this rejection: microorganisms are products of nature and, as a matter of law, living things are not patentable subject matter as defined

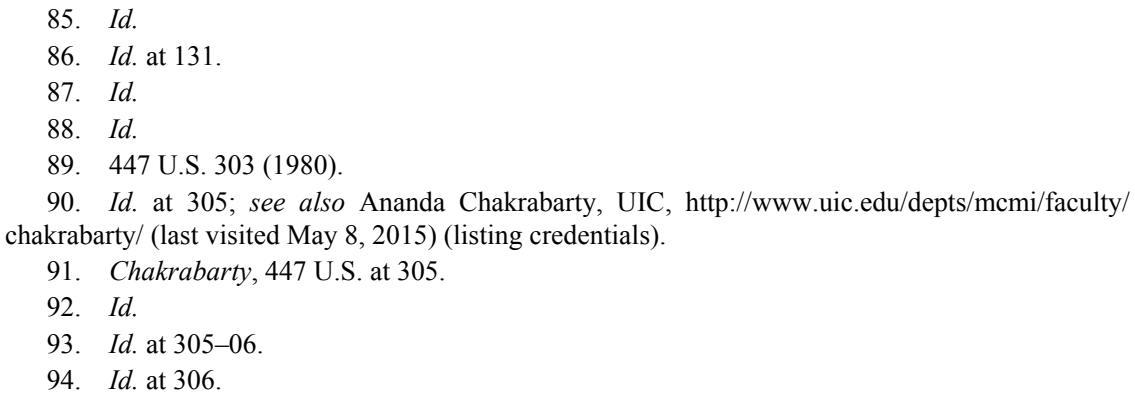


by 35 U.S.C. $\S 101 .^{95}$ Following this rejection, Chakrabarty appealed to the Patent Office Board of Appeals. ${ }^{96}$

On appeal, the Patent Office Board of Appeals affirmed the rejection by the examiner on the grounds that living things are not patentable subject matter. ${ }^{97}$ The Board based its decision on the 1930 Plant Patent Act: according to the Board, the passage of this Act by Congress showed a clear intent to exclude living things from the scope of $\S 101 .^{98}$ However, relying on its decision in In re Bergy, ${ }^{99}$ the Court of Customs and Patent Appeals (CCPA) reversed the Board's decision. ${ }^{100}$ In Bergy, the CCPA held that the mere fact that a microorganism is alive is without legal significance in patent law. ${ }^{101}$ However, following this decision, the Supreme Court vacated the judgment in Bergy, and remanded the case back to the CCPA. ${ }^{102}$ Following reexamination by the CCPA, they reaffirmed their earlier decisions that whether a microorganism was alive was immaterial. ${ }^{103}$ This decision was appealed by the Commissioner of Patents and Trademarks, and the Supreme Court granted certiorari to address the issues present in Chakrabarty. ${ }^{104}$

The Court framed the issue as "whether respondent's microorganism constitutes a 'manufacture' or 'composition of matter' within the meaning of [35 U.S.C. $\S 101]$. ."105 To answer this question, the Court first had to define the terms. "Manufacture" had been defined by the Court to align with its dictionary meaning, that is, as " "the production of articles for use from raw or prepared materials by giving to these materials new forms, qualities, properties, or combinations, whether by hand-labor or by machinery." "106 The Court had likewise construed "composition of matter" in line with its common usage as "all compositions of two or more substances and ... all composite articles, whether they be the result of chemical union, or of mechanical mixture, or whether they be gases, fluids, powders, or solids."107

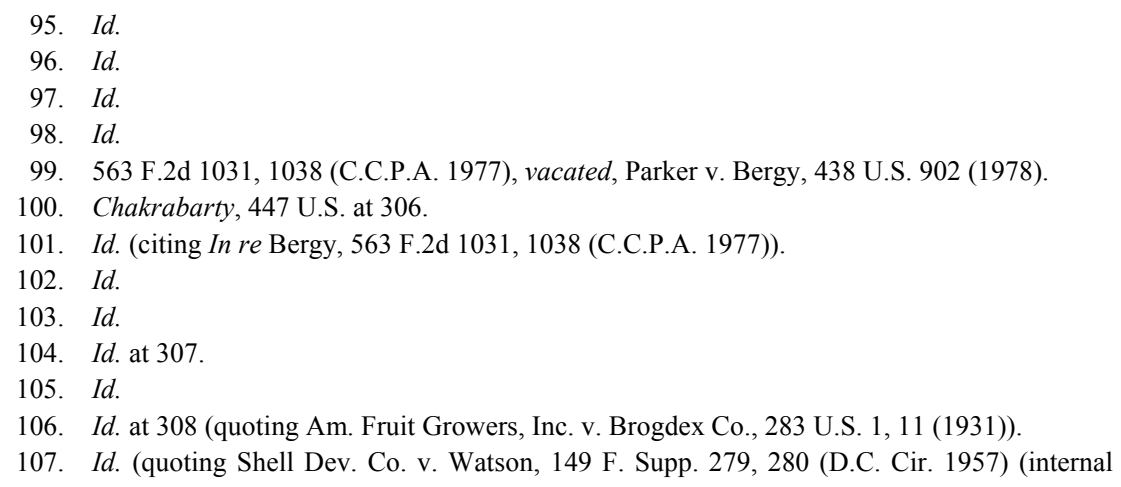


These expansive terms, along with the legislative history of the Patent Act of $1793,{ }^{108}$ show Congress' intent to " include anything under the sun that is made by man" within the confines of $\S 101$. ${ }^{109}$ Despite this seemingly boundless view of patent law, not all discoveries are patentable under $\S 101$ : "laws of nature, physical phenomena, and abstract ideas" have never been held to be patentable subject matter. ${ }^{110}$ These principles led the Court to conclude that Chakrabarty's bacterium was patentable subject matter, ${ }^{111}$ and in doing so placed living objects categorically within the scope of $\S 101 .^{112}$

8. Association for Molecular Pathology v. Myriad Genetics, Inc.

The isolation/purification standard set by the Court in Parke-Davis and Funk would be called into question in the landmark decision Association for Molecular Pathology v. Myriad Genetics, Inc. ${ }^{113}$ The patents at issue in Myriad concerned claims to two genes, BRCA1 and BRCA2, mutations to which caused an increase risk of developing breast cancer. ${ }^{114}$ At issue for the Court were nine composition claims relating to the two genes at issue. ${ }^{115}$ These claims typically operate by claiming the DNA coding that instructs a human cell to produce one of a list of amino acids listed in the patent application. ${ }^{116}$ Also included in the claims was a subset to aforementioned claims: claims to any strand of 15 or more nucleotides within the DNA already claimed. ${ }^{117}$ These claims collective gave Myriad the exclusive right to isolate any strand of 15 or more nucleotides of an individual's BRCA 1 and BRCA 2 genes. ${ }^{118}$ However, the patents were not limited to the naturally occurring BRCA 1

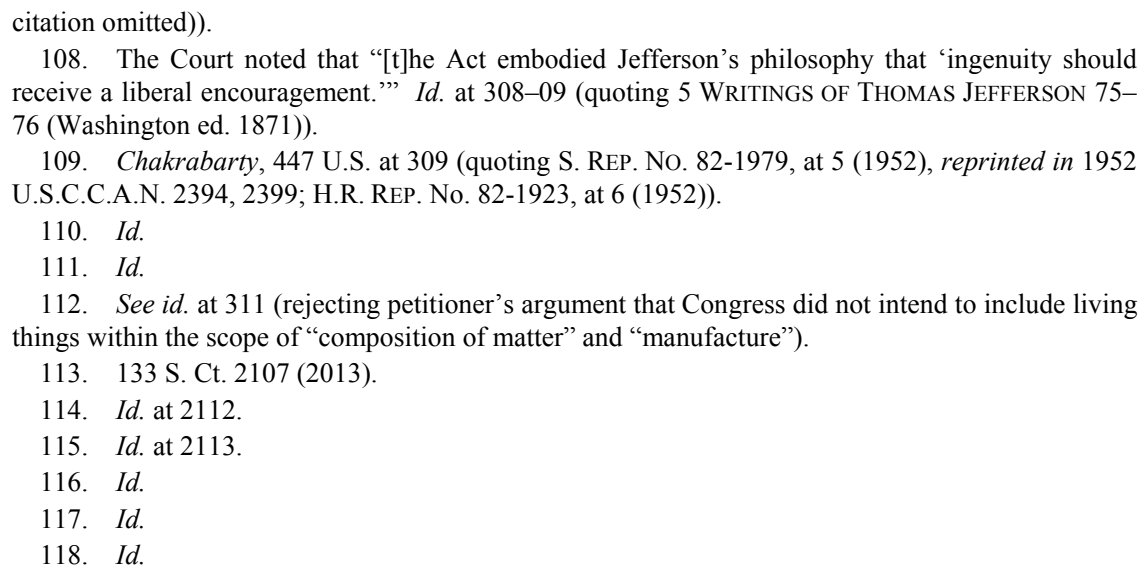


and BRCA 2 genes, but also claimed the cDNA, or synthetically created, sequences of the BRCA genes. ${ }^{119}$

The procedural history of this case is fairly complicated. The lawsuit started when several parties brought a lawsuit against Myriad seeking a declaratory action by the Southern District of New York stating that Myriad's claims were invalid. ${ }^{120}$ The court granted the petitioners motion for summary judgment, holding that the composition claims were invalid as products of nature and thus outside the scope of $\S 101 .{ }^{121}$ On appeal, however, the Federal Circuit reversed the grant of summary judgment in respect to the claims of isolated DNA. ${ }^{122}$ But this reversal was short lived, as the Supreme Court granted certiorari, vacated the judgment, and remanded the case to be reevaluated in light of the Court's decision in Mayo Collaborative Services v. Prometheus Laboratories, Inc. ${ }^{123}$

On remand, the Federal Circuit maintained its position and held that the claims to isolated DNA and cDNA were patent eligible. ${ }^{124}$ However, the Federal Circuit was in disagreement on the question of "whether the act of isolating DNA-separating a specific gene or sequence of nucleotides from the rest of the chromosome-is an inventive act that entitles the individual who first isolates it to a patent." ${ }^{\text {"25 }}$ First, Judge Lourie's conclusion that the isolated DNA was patentable rested on the required breaking of the covalent bonds at each end of the DNA sequence. ${ }^{126}$ In his view, the breaking of these bonds created a new molecule with a new chemical composition and was thus dispositive to the patentability of the isolated DNA, despite the fact that the key feature of DNA, its ability to transmit information, remained unchanged. ${ }^{127}$ Contrarily, Judge Moore did not believe the breaking of the chemical bonds to be sufficient to put isolated human genes in the scope of patentable subject matter, but instead relied on the Patent Office's practice of granting patents as her basis for patent eligibility. ${ }^{128}$ The lone dissenting Judge, Judge Bryson, downplayed the act of breaking chemical bonds, calling it devoid of any "magic" to "require[] us to

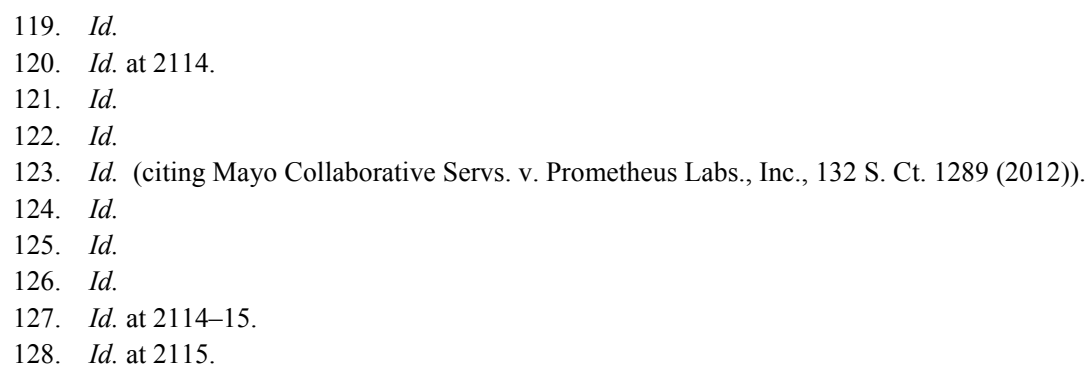


recognize a new product when a chemical bond is created or broken."129 Instead, the dispositive question to Judge Bryson was the substance of the nucleotide sequences: the unchanged genetic structure of the isolated DNA. ${ }^{130}$

The Court started by distinguishing the situation in Chakrabarty. While Dr. Chakrabarty had created a new bacterium with characteristics not found in nature, Myraid had merely discovered a gene and isolated that gene, but had not created anything. ${ }^{131}$ However, discovery, no matter how revolutionary, had never been grounds for patentability under $\S 101 .^{132}$ In the Court's view, this case was much closer to Funk than Chakrabarty: the discovery of the BRCA1 and BRCA2 genes fall within the "law of nature" exception just as the mixture of naturally occurring strains of bacteria did in Funk. ${ }^{133}$ The isolation of the genes is equally inadequate to move the composition claims within the scope of $\S 101 .^{134}$ The claims in no way relate to the chemical structure of the DNA, but instead are based on the genetic information for which the DNA encodes. ${ }^{135}$ Following these conclusions, the Court held "that genes and the information they encode are not patent eligible under $\S 101 . " 136$ However, this holding excludes cDNA and the claims to the synthetic BRCA cDNA at issue here. ${ }^{137}$ The cDNA is unquestionably new and different from the naturally occurring DNA as it is an "exons-only molecule," 138 and is thus patent eligible so long as the cDNA strand is, in fact, distinguishable from natural DNA. ${ }^{139}$

\section{B. Synthesizing a Framework}

With these cases in mind, a working framework can be developed to determine whether a claimed invention falls outside the scope of $\S 101$. The often-overlapping nature of the novelty doctrine and patent eligible

\footnotetext{
129. Id. (quoting Ass'n for Molecular Pathology v. USPTO, 689 F.3d 1303, 1351 (Fed. Cir. 2012) (internal quotation omitted)).

130. Id. at 2115.

131. Id. at $2116-17$.

132. Id. at 2117.

133. Id. at 2116-17.

134. Id. at 2118 .

135. Id.

136. Id. at 2120 .

137. Id. at 2119 .

138. Id.

139. Id. In cases where the naturally occurring DNA is so short as to itself be exon free, the cDNA variety may not be patentable. $I d$.
} 
subject matter doctrine can lead to a conflating of the rules of each. ${ }^{140}$ For that reason it is important to parse through the discussed precedent and separate the rules regarding novelty over prior art from the rules about products of nature.

The Wood-Paper Patent case stands for the proposition that a previously known manufacture is not entitled to a patent simply because it is made by a new process. ${ }^{141}$ Kuehmsted stands for the proposition that a product obtained through the purification of an already existing, nonnatural product, is patent worthy where the purified substance has qualitatively different properties. ${ }^{142}$ Union Carbide stands for the proposition that a new form of an already existing, non-naturally occurring, chemical compound is patentably novel where the new form is not in the prior art, and where the new form provides substantial benefits to that disclosed in the prior art. ${ }^{143}$ Parke-Davis can be said to stand for the proposition that a chemical compound, isolated from nature and then purified, in a form not known in the prior art, is not merely a "degree of purity," of the prior art, but rather a new product altogether. ${ }^{144}$ ParkeDavis should not be extended beyond this holding because, as discussed above, Judge Hand's assertion that an unaltered extract is patent eligible is contrary to all the isolation/purification jurisprudence. ${ }^{145}$

These cases delineate the isolation/purification doctrine as it relates to non-products of nature prior art. However, they do not provide a clear line as to the novelty of purified products. Both Union Carbide and Parke-Davis characterize the patents at issue as "new products" entirely, rather than just purified substances, while the Wood-Paper Patent case expressly declines to address the purification question. The only guidance comes from Kuehmsted. Using Kuehmsted as a guiding principle, a purified form of prior art will be patentable so long as it has qualitatively different properties. Said another way, the isolation/purification doctrine as it pertains to novelty is a fiction. What the court in Kuehmsted essentially held was that the purified form will be

\footnotetext{
140. Richard Seth Gipstein, The Isolation and Purification Exception to the General Unpatentability of Products of Nature, 4 COLUM. SCI. \& TECH. L. REV. 1, 6 (2003).

141. Am. Wood-Paper Co. v. Fibre Disintegrating Co. (The Wood-Paper Patent), 90 U.S. 566, 593-94 (1874).

142. Kuehmsted v. Farbenfabriken of Elberfeld, Co., 179 F. 701, 705 (7th Cir. 1910).

143. Union Carbide Co. v. Am. Carbide Co., 181 F. 104, 106-07 (2d Cir. 1910).

144. See Parke-Davis \& Co. v. H. K. Mulford Co., 189 F. 95, 103 (S.D.N.Y. 1911) ("Nor is the patent only for a degree of purity, and therefore not for a new 'composition of matter.' . . Takamine was the first to make it available for any use ... it became for every practical purpose a new thing commercially and therapeutically.").

145. See discussion supra Part II.A.4.
} 
patentable if it meets all the requirements for patentability (e.g., not anticipated, not obvious in view of the prior art, and has utility). ${ }^{146}$ Therefore, there is no bright-line rule as to when a purified form of prior art will be patent eligible, there are only the existing patent law requirements.

Next in the line of cases was General Electric, which stands for the proposition that merely isolating a product of nature from its environment does not make that product patent eligible. ${ }^{147}$ This was followed by Funk, which stands for the proposition that a mixture of naturally occurring distinct compositions which does not give rise to new properties as a result of the mixing is not patent eligible subject matter. ${ }^{148}$ Chakrabarty then stands for the principle that the designation of a composition of matter as "living" does not remove it from the scope of "composition of matter," and thus is patentable subject matter so long as it is non-naturally occurring and an invention of man. ${ }^{149}$ Myriad stands for the proposition that the separation of a composition from its surroundings does not make the separated composition patent eligible subject matter. ${ }^{150}$

The cases directed to patent eligible subject matter can be reduced down to a basic principle: an isolated or purified composition is not patent eligible subject matter, but is merely a "raw material," if the composition's characteristics were not bestowed on it by the inventor, because the characteristics were not made by man. However, if combined with other raw materials, it could become patent eligible subject matter where the combination results in markedly different characteristics than present in the raw materials. This characterization of the isolation/purification jurisprudence is consistent with viewing the products of nature exception to patentability as an absolute bar to novelty. What is outlined by the cases is essentially a bright-line rule for determining whether the claimed invention is novel relative to the prior art (products of nature).

\section{The Patent Office's Stance on Isolated Organism}

The Patent Office's policy granting patents on "non-naturally occurring, nonhuman multicellular living organisms, including animals"

146. See discussion supra Part II.A.2.

147. Gen. Elec. Co. v. De Forest Radio Co., 28 F.2d 641, 646-47 (3d Cir. 1928).

148. Funk Bros. Seed Co. v. Kalo Inoculant Co., 333 U.S. 127, 131 (1948).

149. Diamond v. Chakrabarty, 447 U.S. 303, 309-10 (1980).

150. Ass'n for Molecular Pathology v. Myriad Genetics, Inc., 133 S. Ct. 2107, 2117 (2013). 
was the result of a notice issued by the Commissioner of Patents and Trademarks in 1987, following the Supreme Court's decision in Chakrabarty. ${ }^{151}$ The Manual of Patent Examining Procedure understands Chakrabarty to stand for four legal principles: (1) "the laws of nature, physical phenomena and abstract ideas' are not patentable subject matter;" (2) if a manufacture or composition of matter is a product of human ingenuity, is non-naturally occurring, and has a "distinctive name, character [and] use," it will be patentable; (3) a mere discovery will not be patentable as they are "manifestations of ... nature, free to all men and reserved exclusively to none;" and (4) articles produced from materials in which the materials are given "new forms, qualities, properties, or combinations whether by hand labor or by machinery" are patentable subject matter. ${ }^{152}$

The Patent Office's definition of "non-naturally" seems to include naturally occurring microorganisms that have been isolated from nature. ${ }^{153}$ This view seems to have been derived from the lower court case, In re Bergy. ${ }^{154}$ This case had been a companion case to Chakrabarty, but was dismissed after Bergy decided to dismiss his claim to an isolated microorganism. ${ }^{155}$ However, mentioned within the lower court's decision was dictum stating that the microorganisms were the patent eligible subject matter "because what was claimed was a biologically pure culture of the organism and the organism did not exist in a pure state in nature." 156

\section{ANALYSIS}

To determine whether the granting of patents on isolated or purified microorganisms is proper, two things must be done. First, it is important to address the foundation of the Patent Office policy to determine its adherence to the patent eligible subject matter case law and to ensure it did not conflate the rules pertaining to novelty with that of patent eligible subject matter. Second, if the underlying foundation is faulty, the next step is to explore whether isolated microorganisms are patent eligible

\footnotetext{
151. 2 Manual of Patent Examining Procedure $§ 2105$ (8th ed. 2008).

152. Id

153. See Schneider, supra note 2, at 593 n.12 (identifying three separate patents on microorganisms isolated from nature).

154. Id.; In re Bergy, 596 F.2d 952, 973 (C.C.P.A. 1979), vacated in part by, Diamond v. Bergy, 444 U.S. 924 (1979), aff'd by, Diamond v. Chakrabarty, 444 U.S. 1028 (1980).

155. See Schneider, supra note 2, at 593 n.12.

156. Id
} 
subject matter according to the earlier determined framework. ${ }^{157}$ This will be done by utilizing existing patents on isolated or purified microorganisms and analyzing the claim language to determine compliance with the framework.

\section{A. The Patent Office's Improper Reliance on In re Bergy}

1. The Facts of In re Bergy

In re Bergy was focused on a patent for a bacterium capable of producing an antibiotic under certain conditions. ${ }^{158}$ However, while this was the subject matter of the case, there was no question of whether the claims were proper patent eligible subject matter, as that had already been decided by the Patent Office. ${ }^{159}$ The two most important claims were claims 1 and 5. Claim 1 read in substantial portion:

A novel process for preparing the antibiotic lincomycin which comprises cultivating Streptomyces vellosus, having the identifying characteristics of NRRL 8037, and lincomycin-producing mutants thereof, in an aqueous nutrient medium under aerobic conditions until substantial antibiotic activity is imparted to said medium by the production of lincomycin. ${ }^{160}$

This claim was not nearly as controversial, as it was a claim to a process utilizing the culture as merely one piece of the process, and processes fall within the defined scope of $\S 101 .^{161}$ Claim 5 was more or less a derivative of this claim, claiming only the bacterium involved in the process of claim 1 :

A biologically pure culture of the microorganism Streptomyces vellosus, having the identifying characteristics of NRRL 8037, said culture being capable of producing the antibiotic lincomycin in a recoverable quantity upon fermentation in an aqueous nutrient medium containing assimilable sources of carbon, nitrogen and inorganic substances.

Claim 5 appears to be the support of the Patent Office's conclusion that isolated and purified microorganisms are patent eligible subject

157. See supra Part II.B.

158. In re Bergy, 596 F.2d at 967.

159. Id. at 955 .

160. Id. at 967 .

161. Id. at $964-65$.

162. Id. at 967 . 
matter. While they were not directly determining the eligibility of this claim, in dicta the court stated "a biologically pure culture produced by great labor in a laboratory" was a far cry from "something preexisting and merely plucked from the earth and claimed as such."163 They further went on to say that if they had understood the separation and identification of strains of microorganisms, they would have perhaps supported the patentability of "something preexisting and merely plucked from the earth.",164

\section{The Flawed Reasoning of In re Bergy.}

The statements of law made by the court in In re Bergy clearly fell outside the established law on products of nature. First, the court's conclusion that "a biologically pure culture" was patentable subject matter was erroneous in view of the products of nature jurisprudence related to products of nature. Perhaps most on point here is General Electric. The biologically pure culture, purified for the first time, is not distinguishable from the elementally pure tungsten, also purified for the first time. In fact, the language of General Electric can be applied directly to the culture at issue in Bergy:

[Bergy] took [the microorganism] as it "existed" (WOs) or as it is found [on] the earth, its native abode, and by his process converted it into [a] pure [culture] ... and, doubtless, was first to discover that when pure it has characteristics ... which are wholly different from the characteristics of the impure [microorganism]. ${ }^{165}$

The same result comes when the facts of Bergy are analyzed according to the entire products of nature framework deduced in Part II.B. The isolated and purified culture's characteristics were bestowed on them by nature itself and were thus not the result of Bergy. ${ }^{166}$ It is immaterial that the isolation required extensive effort because "groundbreaking, innovative, or even brilliant discovery" is not enough to satisfy the requirements of $\S 101$. $^{167}$

The flaw in the analysis is made clearer by again viewing the products of nature exception to patentability as an absolute bar to

\footnotetext{
163. Id. at 976 .

164. Id.

165. Gen. Elec. Co. v. De Forest Radio Co., 28 F.2d 641, 642-43 (3d Cir. 1928).

166. In re Bergy, 596 F.2d 952, 967 (C.C.P.A. 1979), vacated in part by, Diamond v. Bergy, 444 U.S. 924 (1979), judgment aff'd by, Diamond v. Chakrabarty, 444 U.S. 1028 (1980).

167. Ass'n for Molecular Pathology v. Myriad Genetics, Inc., 133 S. Ct. 2107, 2117 (2013).
} 
novelty. The isolated microorganism is not new; it already existed in nature. While it is true that the microorganism did not exist in a "biologically pure culture" in nature, the biologically pure culture was obtained and derived from the existing microorganism. Isolating this bacterium and producing a biologically pure culture amounts to nothing more than the mixing of bacterium that occurred in Funk.

\section{B. Analyzing Current Isolated Microorganisms Under the Isolation/Purification Framework}

The Patent Office's misguided reliance on In re Bergy only answers the question of whether the policy is based on solid precedent; it is not. However, it does not mean that all the patents granted under this policy should have been considered outside the scope of patent eligible subject matter. For example, any patent pertaining to any process utilizing an isolated biological culture is within the bounds of $\S 101$ as discussed above. ${ }^{168}$ To properly demonstrate the isolation/purification framework derived from the case law, examining actual patents provides insight.

\section{The Micromonospora Patent}

The Micromonospora patent contained two claims to a new species of microorganism discovered in soil samples of Danubian mud. ${ }^{169}$ The two claims were to the species as a whole, as well as to a particular strain of the species. Claim 1 read: "A substantially biologically pure culture of the actinomyces species Micromonospora danubiensis having the capability of producing sisomicin upon cultivation in an aqueous nutrient medium." 170

This claim is clearly outside the scope of $\S 101$. The first step of the proposed framework is to determine whether the claimed invention is to an isolation or purification of a substance. The claim here is to the entire species of microorganism isolated from the Danubian mud, ${ }^{171}$ satisfying the first prong of the framework. The next question is whether the microorganism's characteristics were made by man or naturally occurring. According to the patent description, when the actinomyces species was isolated, it already produced sisomicin. ${ }^{172}$ Therefore, this

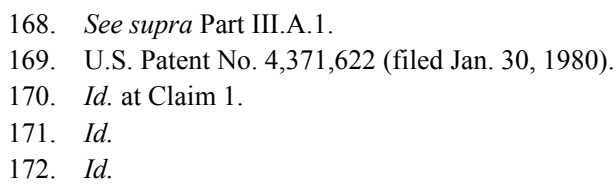


characteristic was not an "invention" made by man, but rather a natural characteristic of the species. Therefore, claim 1 should have been invalidated as a product of nature. In this patent, the remaining framework questions need not be addressed.

Claim 2 read: "A substantially biologically pure culture of the actinomyces strain Micromonospora danubiensis MNG-00171 having the capability of producing sisomicin upon cultivation in an aqueous nutrient medium."173 The analysis of claim 2 will largely mirror that of claim 1 . The only question is whether the additional limitation of only claiming one particular strain of the species moves the claim into the realm of $\S 101$. It is helpful, then, to understand what exactly a strain is. A strain is "a subset of bacterial species differing from other bacteria of the same species by some minor but identifiable difference."174 Thus, whereas claim 1 can be viewed as an isolation claim, this claim is more properly viewed as a purification claim. However, that distinction does not make it patentable.

Applying the isolation/purification framework to claim 2 yields the same result as claim 1. First, the patent is claiming a purification of a substance. The next question is whether the "different strain refining processes" used by the patentee makes the strain "made by man." The answer to this question is clearly no. Similar to the analysis of claim 1, the strain of the microorganism existed with its inherent characteristics before it was "refined" by man. The refining process did not bestow the characteristics to it, but merely identified and isolated the best microorganism for the patentee's task.

\section{The Pseudomonas Gramini Patent}

The Pseudomonas Gramini patent, ${ }^{175}$ which issued as a patent on May 7, 2014, is more complex than the prior patent and contains several more claims as well. These patent claims are worth examining, as it shows one way that claims can be drafted to at least receive some patentable protection on isolated microorganisms, if not on the microorganism itself. Interestingly, the prosecution history of this patent shows just how easy it is to get a patent on isolated microorganisms through the United States Patent and Trademark Office (USPTO).

173. Id. at Claim 2.

174. See, e.g., Biological Control of Pythium Disease in Crops, CA2476531 A1, DESCRIPTION [ [015], GOOGLE PATENTS, http://www.google.com/patents/CA2476531A1?cl=en.

175. U.S. Patent No. US 8,735,136 (filed Dec. 29, 2011). 
Initially, claim 1 reads, "a substantially pure biological culture composition comprising a strain of the species Pseudomonas graminis . ..."176 This strain was obtained by:

[isolating it] from the surface of a "Golden Delicious" apple by means of washing with sterile water, followed by immersion in saline-peptone solution ..., sonication in an ultrasound bath for 10 min and planting the washing liquid in NYDA culture medium..., and subsequent incubation at $25^{\circ} \mathrm{C}$. for 3 days. ${ }^{177}$

The USPTO originally rejected this claim under 35 U.S.C. $\S 101$, because it was directed to a "biological culture of a bacterial strain" and was thus a product of nature. ${ }^{178}$ However, rather than outright rejecting the claim, the Patent Office suggested that "applicant use the language 'isolated' in connection with 'substantially pure biological culture' to identify a product that is not found in nature."179 Thus, according to the Patent Office, the modifier of "isolated" is enough to convert the claimed subject matter into patentable subject matter. How would this amended claim language stand up to the proposed isolation/purification framework?

Applying the isolation/purification framework, this claim will only be patent eligible subject matter if the process by which it was isolated bestowed upon it the characteristics desired in the patent. While the information provided by the patent shows a complicated procedure for isolating the microorganism, this procedure is not responsible for its "effectiveness as an antagonist against foodborne pathogenic bacteria in fruit." 180 Rather, the isolation procedure merely allowed the patent applicant to obtain the best microorganism that already had these characteristics, i.e., the applicant did not invent anything. For that reason, no further analysis through the framework is necessary: this claim should fall outside the scope of patent eligible subject matter as a product of nature.

This patent, however, is not without hope. The patent also claimed a process or method. Claim 17 reads: "A method of treating fruit, said

\footnotetext{
176. U.S. Patent Application No. US 13/976,291, at Claim 1 (filed Dec. 29, 2011).

177. Id. at [0015].

178. See Office Action Summary from USPTO Examiner Qing Xu to Applicant Immaculada Vinas Almenar, USPTO Non-Final Rejection Letter, at 4 (Aug. 8, 2013), available at http://portal.uspto.gov/pair/PublicPair (search for Patent Application 13/976,291, then click on "Image File Wrapper" tab and scroll down).

179. Id.

180. U.S. Patent Application No. US 13/976,291, at [0013].
} 
method comprising the step of: applying a preparation to a fruit, wherein the preparation comprises a culture of a strain of a species Pseudomonas graminis ...."

This claim is entitled to a patent, as it is not limited to a product of nature, but rather is to a process, which is patent eligible subject matter expressly defined in 35 U.S.C. $\S 101,{ }^{182}$ so long as it meets the remaining requirements of patentability. While the distinction between a claim to the microorganism and a claim to the process utilizing the microorganism for its natural characteristics may seem subtle, processes have long been held to be patentable, even if the products used in that process are not. ${ }^{183}$ Thus, ending the practice of granting product patents on isolated organisms would not leave the patent without options.

\section{CONCLUSION}

The purpose of the patent laws was to foster ingenuity and inventiveness by rewarding people who contributed to society by advancing technology and the arts. The granting of patents on isolated microorganisms does not serve that purpose. The law is developed in a way to ensure that only those inventions that furthered this goal would be granted a patent. However, because of a conflation between the doctrines of novelty and patentable subject matter, patents are being granted that were never intended to be granted.

The patent law jurisprudence establishes that while purification and isolation may, in some circumstances, satisfy the patent law requirement of novelty over the prior art, it still does not qualify as patentable subject matter if it is the mere isolation or purification of nature. The framework developed by this Comment more accurately reflects this jurisprudence: it adheres to the intent of the founders and the precedent of the courts that has been developed for over a century. The Patent Office should reconsider its policy of granting patents on isolated microorganisms, and adopt a policy that accurately reflects the law. If the Patent Office does not change its policy, these patents will continue to be granted until the Supreme Court is faced with the question.

The granting of these patents is a disservice to society. By granting a monopoly to an entire species of an isolated microorganism, it allows the patent owner to preclude others from experimenting with and advancing

181. Id. at Claim 17.

182. 35 U.S.C. $\$ 101$ (2012).

183. See In re Bergy, 596 F.2d 952, 977 (C.C.P.A. 1979), vacated in part by, Diamond v. Bergy, 444 U.S. 924 (1979), judgment aff'd by, Diamond v. Chakrabarty, 444 U.S. 1028 (1980). 
possible biosciences relevant to that microorganism. The granting of only process claims involving isolated microorganisms far better serves the public. By doing so, the patent owner only gains a monopoly on the microorganism for as far as the patent owner has created a new and useful process for it; the patent owner does not gain unlimited control of the microorganism, leaving it open for others to come in and advance the art. 